\title{
The Politics Behind the Introduction of Stirring Up Religious Hatred Offences in England and Wales
}

Alexander Brown (UEA)

\section{Introduction}

The Racial and Religious Hatred Act 2006 amended the Public Order Act 1986 to create new stirring up religious hatred offences in England and Wales, making it an offence, amongst other things, to use threatening words or behaviour or publish threatening words or distribute threatening materials, recordings or videos with the intention of stirring up hatred against people on grounds of their religion, albeit with a freedom of expression proviso protecting discussion, criticism and ridicule of religious beliefs and practices. ${ }^{1}$ But what was and is the real function of the new stirring up religious hatred offences in England and Wales from the perspective of government, parliamentarians and the judiciary?

This question has already attracted some attention from legal scholars, and the most common conjecture is that the real driving force behind the Racial and Religious Hatred Act 2006 was for the Labour government to provide a sop to Muslims: to take with one hand from British Muslims, in the shape of draconian anti-terrorism laws, but give back with the other, in the form of protection against the stirring up of religious hated. ${ }^{2}$ Yet there has also been a lack of systematic, historical analysis of the question: both in terms of testing the validity of the sop explanation and in terms of identifying and assessing rival explanations. This article is in some small way an attempt to put that right. I am partly engaged, therefore, in a critique of the explanations found in the existing literature on this subject, but also partly concerned with evaluating potential explanations identified for the purposes of this inquiry.

Why does an inquiry into events of more than a decade ago matter? I believe that it is inherently important to try to understand something of the politics behind the introduction of the new offences as an exercise in political history. But no doubt this investigation has other potentially significant implications, including gaining a better understanding of the true scope of anti-terrorism policy agendas in England and 
Wales, re-evaluating the nature of the New Labour project, uncovering inconsistencies in the Prevent strategy, shedding light on the political position of the Muslim community in England and Wales, or even testing general theories of public policy and the dynamics of legislative change. However, my own particular interest is in teasing out how the best explanation of the true purpose behind the stirring up religious hatred offences bears on the many normative arguments that have been made about the rights and wrongs of these laws, including arguments about further extensions covering transgender identity and disability. I shall argue that although it might be perfectly possible to normatively evaluate these laws without understanding the real functions they were and are supposed to serve, it is much harder to do so in ways that stand a decent chance of impacting future governmental, parliamentary and judicial decisions.

This article tries to explain the politics behind the introduction of the new stirring up religious hatred offences by examining not only the justifications provided by elected politicians, government ministers and peers at the time but also the wider context of legislation and the political environment, including the strategic aims of the Labour Party as set against the de facto power of members of the House of Lords to slow the passage of legislation, and also how the legislation has actually been used in practice by courts in England and Wales. In casting the evidential net so widely I do not mean to ignore or blur the distinction between the point of the Racial and Religious Hatred Act 2006 as seen from the government's perspective, parliament's perspective and a judicial perspective. Clearly such perspectives can, and often do, come apart. So where I do draw on evidence from post-enactment events (court decisions, political speeches made later on), I do so only in highly qualified ways. Nevertheless, one general point worth emphasising here is that since any public policy, including public policy on hate speech, is constituted not only by legislative acts that implement the will of the government but also by constitutional protections embedded in the principles of parliamentary supremacy and by judicial decisions applying those legislative acts to the circumstances of actual cases, it would be impossible to fully understand the politics behind the introduction of the stirring up religious hatred offences without knowing something of the perspectives of government, parliamentarians and the judiciary. Indeed, it is also important to note that under s. 29L of the Racial and Religious Hatred Act 2006 it is the Attorney General, a position appointed by the sovereign on the advice of the Prime Minister, 
who must approve all prosecutions, and this fact alone inevitably brings some of the government's intent into the courtroom. In other words, my aim is not merely to explain the Racial and Religious Hatred Act 2006 but also to explain the broader and ongoing public policy on incitement to hatred in England and Wales.

Drawing on this evidence I identify five possible accounts of the real function of, and true explanation for, the introduction of the new stirring up religious hatred offences. One of these accounts (the sop explanation) has already gained traction among academics as well as among some journalists and social commentators, but I seek to see how far it, along with alternative rival accounts, can be substantiated based on the available evidence. First, the public order explanation is that the government introduced laws banning the stirring up of religious hatred in response to mass disturbances and riots that had taken on more complex racial, ethnic and religious dimensions since the Race Relations Act 1965. Second, the sop explanation is that the government only developed a serious interest in the problem of the stirring up of religious hatred after the 9/11 twin towers attack in 2001 and the $7 / 7$ London bombings in 2005 respectively, and only legislated new stirring up religious hatred offences as a way of sweetening the pill of anti-terrorism legislation for the Muslim community affected by it. Third, the anti-terrorism explanation puts the existence of the new stirring up religious hatred offences squarely down to the fight against Islamist terrorism, and security concerns over the potential for further atrocities like 9/11 and 7/7 off the back of radical Muslim clerics and extremist Islamist activists stirring up religious as well as racial hatred. Fourth, the client politics explanation shifts the focus from Muslims as stirring up religious hatred to Muslims as the victims of the stirring up of religious hatred; the idea being that a concentration of the burden of hate speech on Muslims produced a highly motivated, mobilised and persuasive lobbying group. Fifth, the parity of protection explanation points to the more basic point that, due to the way legal authorities defined 'race', Muslims did not enjoy legal protection against the stirring up of racial hatred at a time when other groups that also partly identified themselves in religious terms, namely, Jews and Sikhs, did enjoy such protection.

In what follows I present and critically evaluate each of the aforementioned explanations in turn. In the end I come down on the side of a pluralistic approach, one that combines the public order explanation with the client politics explanation in conjunction with the parity of protection explanation, whilst deemphasising the sop 
explanation and the anti-terrorism explanation. Finally, I try to spell out some implications of this largely historical analysis for how legal scholars today argue about and seek to normatively reject or defend incitement to hatred laws and the extension thereof to new categories of people.

Before I begin, however, I also want to make the crucial methodological point that when it comes to the interpretation of events dating back over a decade we are certainly not in the terrain of incontrovertible evidence. That is why I shall not say that the public policy on incitement to religious hatred we have in England and Wales cannot possibly have the chief purpose that a given explanation claims for it based on the available evidence. It is more a matter of sifting through the evidence and taking it as a whole. There are no smoking guns here, merely a balance of probabilities.

\section{The public order explanation}

The public order explanation draws strength from the history surrounding the introduction of the racial hatred offences. Following the end of the Second World War Britain saw a significant increase in immigration from the West Indies, India, Bangladesh and Pakistan. This was partly Britain's recognition of the role played by the Commonwealth in the war effort, partly Britain's post-colonial settlement, and partly a response to the need for labour in building British infrastructure and public services. By 1958, however, some parts of Britain, most notably Notting Hill in London, were the scene of racial violence and riots between whites and West Indian blacks. Latent tensions were sparked when a white Swedish woman who was married to a West Indian man was assaulted by a group of white men. These events fed into a larger national conversation about race relations in Britain. It was a conversation that would go on to encompass Enoch Powell's infamous 'rivers of blood' speech in the summer of 1968, in which he issued dark warnings about threats to public order if questions of immigration and integration were not satisfactorily resolved.

Against this backdrop, the Race Relations Act 1965 sought to provide a framework of fair expectations between divided sections of British society, and included the introduction of new stirring up racial hatred offences. At the time several parliamentarians suggested the idea of incorporating religion as well as racial hatred 
within the scope of the offences, but Dingle Mackintosh Foot, then Solicitor-General, rejected the idea. He claimed that it would be undesirable on free speech grounds.

Both the tenets and the practices of various religious denominations are the subject of violent differences and of perfectly legitimate controversy. There is all the difference in the world between attacking a section of the public because of the colour of their skins and attacking them because, say, they subscribe to the Thirty-Nine Articles. ${ }^{3}$

He also claimed that it would be unnecessary.

I agree - we all agree - that nothing is more loathsome and more contemptible than expressions of anti-Semitism. But those expressions are not, at any rate in 99 cases out of 100 , based on theological considerations. When there are attacks upon the Jews [...] they are not directed merely against those who observe the Mosaic law. They are directed against Jews as a race. ${ }^{4}$

In fact, the idea of including religion within the scope of the stirring up hatred offences never disappeared entirely from parliamentary debates on issues of race relations for the next two decades. ${ }^{5}$ But the idea continuously butted up against the sorts of objections articulated above by Dingle Mackintosh Foot.

In the meantime, Britain continued to see mass disturbances and riots. In 1995, a district of Bradford, West Yorkshire, was the scene of three days of rioting, including violence between the police and South Asian residents. Then again, in 2001 both Bradford and Burnley saw conflict between the city's British Asian population and its white British residents, fuelled by the activities of far right groups including the British National Party and the National Front. In 2005, in Birmingham, there was conflict between people with Afro-Caribbean origins and people of South Asian descent, triggered by unsubstantiated allegations of the gang rape of a black teenage girl by a group of South Asian men. What had previously been public disorder based on racial tensions and rooted in economic deprivation, now took on complex racial, ethnic and religious dimensions, relating not merely to poverty but also in some 
instances to minority religious identities (Muslim, Sikh, Hindu) that people felt they needed to assert.

During this period the Labour government made a series of attempts to introduce new legislation making it an offence also to stir up hatred on grounds of religion. It tried unsuccessfully via the Anti-Terrorism, Crime and Security Bill in 2001 and the Serious Organised Crime and Police Bill in 2004, introduced by Jack Straw's successor as Home Secretary, David Blunkett. Then it succeeded via the Racial and Religious Hatred Bill in 2005 and, ultimately, the Racial and Religious Hatred Act 2006, introduced by David Blunkett's successor as Home Secretary, Charles Clarke. According to the public order explanation, the introduction of the legislation was a direct response to, and triggered by, the fact that mass disturbances and riots were not going away and were becoming increasingly more complex, meaning religion could no longer be left out of the equation in understanding them. Moreover, the inclusion of the stirring up religious hatred offences within the Public Order Act 1986 was not mere convenience but went to the heart of the real function of the offences.

From the perspective of process tracing, it is difficult to argue with the timings of the various events described above, with the putative causes and effects in their correct temporal sequences. On this explanation, one looks at these events in terms of an evolving public policy response to an evolving problem: as mass disturbances and riots (public disorder) became more complex, so did the public policy response, in the shape of new public order offences.

In addition, the speeches of successive Home Secretaries clearly indicate a concern with public order. As David Blunkett put the matter when addressing the House of Commons in November 2001, '[t]his is a public order Act, and it is the order that we are talking about. ${ }^{6}$ Or, consider the words of Charles Clarke during the second reading debate on the Racial and Religious Hatred Bill in June 2005.

I [...] begin by emphasising that the Bill deals with hatred and incitement to hatred. It is about the nasty and extreme behaviour that drives people to hate others and sometimes, as the recent desecration of Jewish cemeteries shows, to turn that hatred against people and property. It is about behaviour that destroys individuals' lives and sets one community against another. In evidence to the House of Lords Select Committee on religious offences, the Association of Chief Police Officers said that hatred stirred up by extremist 
groups contributed to the Bradford and Burnley riots in 2001. The Bill is intended to help tackle that sort of hatred - I emphasise "hatred". 7

Of course, it might be countered that just because the Home Secretary referred to the public order nature of these offences it does not prove that the government definitely did not see these offences as also potentially being used to prevent the spread of extremist ideologies or acts of terrorism, for example. Indeed, the very concept of public order is not necessarily limited to mass disturbances and riots. I take the point. This bit of evidence is not conclusive. But the real issue is whether or not the evidence as a whole suggests that public order was the primary concern. The aforementioned evidence suggests that it was.

The public order explanation is also borne out in some of the ensuing case law. One interesting case involved the stirring up of religious hatred by Sikhs against Muslims. In R. v. Singh, Singh Athwel, Singh, Baning, and Singh three of the defendants pleaded guilty to publishing material intended to stir up religious hatred against Muslims, contrary to section 29C of the Public Order Act 1986. This related to contributions they made to a Facebook page they had set up for the purposes of discussing the need to be mindful of atrocities committed by Muslims, to prevent sexually motivated attacks by Muslim men on Sikh women and generally to beware the threat posed by Muslims. In her sentencing remarks Judge Dean described the general 'tone of the conversation' on the Facebook page as 'one of an immediate wish to use gratuitous violence against Muslims, effectively, for the simple reason that they are Muslims and Muslims were being regarded in the conversation as deserving of violence.' ${ }^{9}$ Judge Dean also made four references to 'tensions' between Sikh and Muslim communities in Leicester. At heart, this case was about a concern on the part of the police, the Crown Prosecution Service (CPS), the Attorney General and Judge Dean about public order - a concern that the use of threatening words on Facebook could further heighten tensions between these ethno-religious groups and lead to violence and mass disturbances. Indeed, it is notable that the defendants were also convicted of various offences relating to the importing and possession of dangerous weapons including knives, knuckledusters, Tasers, pepper sprays, and batons, and to persuading people to travel to various locations around Leicester carrying these weapons. The two groups were gearing up for a mêlée on the streets of Leicester during which they and innocent members of the public could get hurt. That the court 
treated the problems being tackled by the offences as principally public order problems tells us something of the real function of the wider public policy on incitement to religious hatred.

Despite all this, however, the public order explanation is not the dominant explanation in the literature. In fact, it hardly receives a mention next to the explanation which is dominant, to which I shall now turn.

\section{The sop explanation}

The dominant account of the real function of, or explanation for, the new stirring up religious offences runs as follows. In the 1960s the government set out to restrict immigration - as a response to concerns about the threat to social cohesion posed by excessive immigration - but to balance off the negative impact of these restrictions on existing immigrant families it also created the stirring up racial hatred offences, as a way of protecting these groups. Similarly, in the 2000s the government wished to introduction tough new anti-terrorism laws ${ }^{10}$ - to respond to concerns about the threat to security posed by Muslim extremism - but to offset the negative impact of these laws on the Muslim community it introduced new stirring up religious hatred offences (the existing stirring up racial hatred offences protected Jews and Sikhs as racial or ethnic groups but not Muslims as a religious group). This is the sop explanation: a strategy, or ploy, devised by the Labour government to take with one hand from British Muslims but to give back with another. ${ }^{11}$ (Of course, among the implicit factual premises built into the sop explanation is that anti-terrorism legislation was and is specifically targeted against the Muslim community, whether by design or effect; which is, of course, something governments may deny.)

One way of motivating the sop explanation is to consider the timing of the Labour government's attempts to introduce new stirring up religious hatred offences, first via the Anti-Terrorism, Crime and Security Bill in 2001 and then again via the Serious Organised Crime and Police Bill in 2004-5 and, finally, via the Racial and Religious Hatred Bill in 2005-6. It is no coincidence (the argument goes) that these bills were introduced in the wake of extremist Muslim terrorist atrocities, 9/11 and 7/7, and at times when the government was also introducing new anti-terrorism legislation in response to those atrocities. This timing at least seems to bear out the sop explanation. 
If the Labour government had independent reasons to provide Muslims with new laws protecting them from the stirring up of religious hatred - reasons that had nothing to do with ameliorating the negative impact of anti-terrorism laws on the Muslim community - then one could have reasonably expected the Labour government to have been minded to provide these protections before its plans for anti-terrorism laws were developed. Yet prior to $9 / 11$ the Labour Government had not clearly signalled any intention to introduce new stirring up religious hatred offences. ${ }^{12}$ The facts are that the introduction of new stirring up religious hatred offences did not make an appearance in the Queen's Speech until 2004 (and then again in 2005), ${ }^{13}$ and did not figure in a Labour Party general election manifesto until 2005. ${ }^{14}$ This timing was certainly not lost on certain members of the House of Lords when it came to debating the Anti-Terrorism, Crime and Security Bill in November 2001. In the words of Lord Waddington, '[draft legislation on the stirring up of religious hatred] has precious little to do with the events of September 11th, except in the sense that after September 11th it was offered to the Muslim community as a kind of sop to buy support for the war against terrorism.' 15

Then again, not all the evidence stacks up for the sop explanation. In 2005, for example, Charles Clarke allegedly wrote to several mosques to explain that on the 5 th of April, against the wishes of the Labour government, an amendment had been passed in the Lords that removed stirring up religious hatred offences from the Serious Organised Crime and Police Bill. ${ }^{16}$ Yet the letter makes no mention whatsoever of security and terrorism, anti-terrorism measures or the negative impact of such measures on the Muslim community. If the real function of the new offence had been to placate the Muslim community, perhaps the letter would have said something along these lines "We recognise the special role that the Muslim community is playing in tackling extreme Islamist ideology and terrorism, and that the burden of anti-terrorism measures have often fallen on Muslims, but we want to reassure you that we take the interests of the Muslim community extremely seriously, and so we are finally introducing new stirring up religious hatred offences."

Of course, it might be argued that if the Labour government was attempting to soften the blow or in some sense compensate the Muslim community for antiterrorism measures - measures which the Muslim Council of Britain, for example, argued were targeted at the Muslim community - maybe the wise move would be not to make this explicit to Muslims. It might backfire on the government to admit that its 
anti-terrorism measures are most likely curb and restrict the activities and freedoms of people from the Muslim community. Then again, if a group in society perceives that is facing burdens from anti-terrorism laws, and is alienated, disillusioned, and angry partly because of that perception, and one wishes to make amends, it might be a missed opportunity not to point out that introducing new stirring up religious hatred offences is designed to offer them something that improves their position.

There is another version of the sop explanation that is perhaps even weaker. It is that the introduction of the new stirring up religious hatred offences in 2005 was supposed to be compensation for the fact that the Labour government had pursued the war in Iraq - a war that was waged in a country populated by Muslims and, therefore, a war that Muslims might view unfavourably either simply as causing the unnecessary deaths of Muslims or as a declaration of war against the entire Islamic Ummah. This version of the sop explanation, however, is severely undermined by the fact that the Racial and Religious Hatred Bill was not the first attempt made by the Labour government to introduce the new offence. In the words of the then Labour MP (now Mayor of London) Sadiq Khan, during the second reading debate on the Racial and Religious Hatred Bill in the House of Commons in June 2005:

The third objection is that this is a sop to the Muslim community, giving them preferential treatment because of the Iraq war. [But] the first time the then Home Secretary, my right hon. Friend the Member for Sheffield, Brightside (Mr. Blunkett) tried to introduce this legislation was in winter 2001 - more than a year before the war with Iraq - so I am afraid that the chronology of those who make that point is simply wrong. If British Muslims really were as powerful and influential as the hon. Member for Henley (Mr. Johnson) suggests, one would have thought that they could have persuaded the Government not to fight the Iraq war in the first place. ${ }^{17}$

A more plausible argument, at least in terms of the sequence of events, might be to argue that the legislation was a sop to the Muslim community for the government's failure to intervene to prevent the genocide and ethnic cleansing carried out against Bosniak citizens (Muslims) during the Bosnian war from 1992-1995. This, at least, predates the various attempts to legislate mentioned above. But here it is arguable that if the genocide was relevant to the creation of new stirring up religious hatred 
offences, it was less likely to be because the new offences amounted to paying a debt to the Islamic Ummah and more likely to be because the government recognised patterns in history in which speech that stirs up ethnic or religious hatred ends in acts of genocide. In other words, the government could be interpreted as learning the lessons of the Bosnian genocide, along with the Rwandan genocide and, going further back, the Holocaust, about the sometimes devastating effects of incitement to hatred and the creation of a climate of hatred. I shall return to these ideas below.

In summary, it is arguable that the evidence which exists for the sop explanation is weak, and the counter evidence relatively strong. It is intriguing, therefore, that this has been the dominant explanation in the literature, even to the exclusion of other rival explanations. Perhaps one reason for this dominance might be the sort of literature involved. With the exception of Erik Bleich, the sop explanation has almost always popped up in articles and books written by legal scholars, as opposed to historians, political scientists and political theorists. A second, related reason may be that, within the relevant literature, the project of explaining why Britain introduced stirring up religious hatred offences tends to be of secondary, or minor importance, compared to the primary goal of critiquing the legislation. If an author is of the view that the legislation is bad legislation - perhaps because the author believes the law is badly drafted, unnecessary, ineffective, or has unjustified implications for freedom of expression - it is perhaps a convenient, similarly negative conclusion to draw that the motivations for the legislation were also compromised in some way. Among some social commentators, the sop explanation might also feed into a broader scepticism about ideas of multiculturalism and the New Labour project more generally. To embrace the sop explanation is to embrace the idea that attempting to recognise the special grievances of religious minorities, most notably Muslims, inevitably gets mired in difficult policy dilemmas and may cause the sacrifice of liberal freedoms; or belies a highly cynical strategy on the part of an electorally unsuccessful political party to assiduously accumulate a winning coalition of voters, whatever the cost.

\section{The anti-terrorism explanation}

A third explanation of the introduction of the new stirring up religious hatred offences makes a direct appeal to matters of terrorism and national security. Whereas the sop 
explanation plays up the fact that the new offences prohibit the stirring up of religious hatred against Muslims, the anti-terrorism explanation instead highlights the fact that the new offences prohibit the stirring up of religious hatred by Muslims. In short, the new offences were introduced in the wake of $9 / 11$ and $7 / 7$ in an attempt to prevent radical Muslim clerics and extremist Islamist activists from engaging in incitement to hatred against Jews, Christians, and non-believers in general, of a sort that could ultimately lead to the spread of extremist Muslim ideology and terrorist atrocities.

According to the anti-terrorism explanation, it is no coincidence that the Labour government initially sought to introduce the new stirring up religious hatred offences via the Anti-Terrorism, Crime and Security Bill in 2001. In other words, its place in the Bill is not to be explained merely by the fact that adding new offences would be more efficiently achieved by adding the necessary amendments into an omnibus or bundle legislative bill - given that parliamentary time to pass new legislation is an incredibly scarce resource for any government - or by the fact that the Labour government anticipated that introducing the new offences would be controversial so it chose to hide the amendments in an high-profile bill and it just so happened to be an anti-terrorism bill. Rather, the introduction of the new stirring up religious hatred offences by means of the Anti-Terrorism, Crime and Security Bill reveals something about how the Labour government viewed the true purpose of the offences, the real problems the offences were intended to address.

If the real function of the new offences was to tackle threatening speech that stirs up religious hatred in ways that pose a threat to national security, this implies that the government believed this function was not being adequately fulfilled or could not be adequately fulfilled by the existing stirring up racial hatred offences. Given the value of parliamentary time as a scarce resource for implementing the government's policy agenda, and assuming that senior civil servants in the Ministry of Justice, the Home Office and the CPS would have fully briefed both the Minister of State and the Home Secretary about the current state of incitement to hatred law, including successful and unsuccessful prosecutions under the law, then the current explanation only makes sense if the government had seen loopholes in the current offences as far as the protection of security is concerned.

Here, at least, there is some evidence to support the explanation. The evidence comes directly from the case law. It is certainly true that the existing stirring up racial hatred offences had been put to use in the name of security, not merely from the 
government's perspective but also from the perspective of judges at the coal face. Consider R. v. El-Faisal. ${ }^{18}$ In this case police investigating possible al-Qaeda links in the UK found tape recordings of speeches given by the Jamaican-born Muslim cleric, Abdullah el-Faisal, labeled 'No peace with the Jews' and 'Jewish Traits'. He was convicted inter alia of two counts of distributing threatening recordings with intent to stir up racial hatred - the first Muslim cleric to be convicted of such offences in England and Wales. For each of the two counts El-Faisal received a sentence of twelve months imprisonment. In his sentencing remarks Judge Beaumont seemed clear that the offence is taken extremely seriously due in large measure to the threat that the stirring up of racial hatred will lead impressionable people to take up arms. As he put it:

In my judgment, your offending was aggravated by the fact that as a cleric you were sent to this country to preach and minister to the Muslim community in London, and so had a responsibility to the young and impressionable within that community at times of conflict abroad and understandable tensions in the communities here over the period which is spanned by the indictment. Instead of calming fears, you fanned the flames of hostility, and furthermore, as I have said already, your words were not confined to the study circles you addressed but recorded to be distributed to bookshops for sale to the public, packaged as they were in the tape covers which were exhibited in the course of this trial, and to me it rang hollow for you to say in evidence that none of the young men to whom you preached went off to fight in Afghanistan or Chechnya or Kashmir. No-one, least of all you, will ever know. ${ }^{19}$

This is far from being an isolated case. Consider also R. v. Iftikhar Ali, ${ }^{20} R . v$. Hamza, $^{21}$ R. v. Rahman, ${ }^{22}$ R. v. Javed, ${ }^{23}$ R. v. Saleem ${ }^{24}$ - all of which involved successful prosecutions of either radical Muslim clerics or extremist Islamist activists for stirring up racial hatred offences - the last three of which concerned the Danish embassy demonstrations in February 2006 and all of which involved parallel convictions for terrorism related offences. More importantly, although there have been far fewer convictions under the new stirring up of religious hatred offences, these offences certainly have been used in some instances for the purpose of tackling 
extremist Islamist ideology and potential seeds of terrorism. In R. v. Ahmad, ${ }^{25}$ for example, a dual nationality British-Pakastani business information technology graduate using the pseudonym Abu Jahiman engaged in an on-line discussion via the website IslamicAwakenings.com concerning a college in India that had allegedly banned its students from wearing the Burka. Mr. Ahmad wrote that '[Muslims] should storm these filthy rabid sub-monkeys and stomp on their jaws until they hear the sweet crack sound and then some.' For this he was found guilty on one count of publishing written material with intent to stir up religious hatred and given a one year sentence. In his sentencing remarks Justice Royce was not explicit about members of which religious group were having hatred stirred up against them by Mr. Ahmad, but the facts of the case suggest members of the Hindu faith. Mr. Ahmad was also convicted for various other serious terrorist and criminal offences relating to the publication of extremist Islamist views on the Internet. The total sentence was 17 years. In passing sentence Justice Royce used phrases such as 'your views were corrosively dangerous', 'a significant risk to members of the public', 'public protection', 'a viper in our midst willing to get as many as possible to strike at the heart of Parliament and of our system'. ${ }^{26}$ Whilst many of these phrases were clearly aimed at the more serious offences, the judge does not explicitly exclude the stirring up religious hatred offences from the scope of these phrases, nor does the overall thrust of the sentencing remarks point toward that restriction of scope. What all of this shows is that there was indeed potentially a gap in the law which meant that prior to 2006 a radical Muslim cleric or extremist Islamist activist could in theory stir up hatred against Hindus or Christians, say, without fear of prosecution, and in so doing pose a potential threat to national security.

Indeed, the anti-terrorism explanation might also draw strength from other similar measures taken by the Labour government, and continued by the Conservative government, to prevent radical Muslim clerics and extremist Islamist activists from peddling hatred in England and Wales, the justifications for which make explicit reference to terrorism and threats to national security. For example, Art. 320(6) of the Immigration Rules sets out the following grounds on which entry clearance or leave to enter the country can be refused: 'where the Secretary of State has personally directed that the exclusion of a person from the UK is conducive to the public good.' In August 2005, in the wake of the 7/7 London bombings, Charles Clarke set forth an 
indicative list of 'unacceptable behaviours' to be used as bases for such exclusions, including the following:

- Writing, producing or distributing material;

- Public speaking including preaching

- Running a website; or

- Using a position of responsibility such as teacher, community or youth leader

To express views which:

- Format, justify or glorify terrorist violence in furtherance of particular beliefs;

- Seek to provoke others to terrorist acts;

- Foment other serious criminal activity or seek to provoke others to serious criminal acts or;

- Foster hatred which might lead to inter-community violence in the UK. ${ }^{27}$

The then Prime Minister, Tony Blair, explicitly linked these new measures to 'the terrorist threat in Britain' and to 'national security'. ${ }^{28}$ Interestingly, this list of 'unacceptable behaviours' has been tested and upheld as lawful by the courts in subsequent cases. In Naik v. The Secretary of State for the Home Department, ${ }^{29}$ for example, the High Court of Justice (Admin.) upheld a decision taken in June 2010 by the then Home Secretary (and now Prime Minister), Theresa May, partly on the advice of the director general of the Office for Security and Counter Terrorism ("OSCT"), Charles Farr, to exclude an Indian national and Muslim writer and orator from entering the UK. The letter stated that Dr. Naik was to be excluded 'for engaging in unacceptable behaviour by making statements that attempt to justify terrorist activity and fostering hatred.' The Court accepted that the exclusion order was 'necessary for, and proportionate to, the legitimate aims of protecting national security, preventing crime and protecting the rights of others. ${ }^{30}$ This decision was subsequently upheld by the Court of Appeal (Civ.). Notably, the higher judgement contains 15 references to 'national security' but only 4 references to 'public order'. ${ }^{31}$

Advocates of the anti-terrorism explanation might suggest that the real function of the public policy on incitement to religious hatred - although not the proximate cause of the Racial and Religious Hatred Act 2006 itself - has continued to reveal itself 
over time as politicians have in their speeches, wittingly or unwittingly, combined discussion of anti-terrorism measures, such as the encouragement of terrorism and the glorification of terrorism offences, with discussion of the offences. One such example is a statement on national security issued by the office of the then Prime Minister, Gordon Brown, in November 2007 which talks in the main about the threat of terrorism and various anti-terrorism measures, including tackling those who use the Internet for the purposes of the encouragement of terrorism, but also mentions in passing that 'the Home Secretary is inviting the largest global technology and internet companies to work together to ensure that our best technical expertise is galvanised to counter online incitement to hatred. ${ }^{32}$ The discursive linking together of the stirring up hatred offences with issues of terrorism and national security has to some extent continued with the Conservative government through its reinvention of the Prevent Strategy, a set of policy measures aimed at challenging the ideological roots of terrorism as much as tackling the threat of terrorist atrocities themselves. Interestingly, in her Foreword to the publication of the new Prevent Strategy document in June 2011, Theresa May stated boldly:

The Prevent programme we inherited from the last Government was flawed. It confused the delivery of Government policy to promote integration with Government policy to prevent terrorism. ${ }^{33}$

Given this statement, it could seem indicative that, as well as discussing a range of anti-terrorism measures, this same Prevent Strategy document also throws into the mix the stirring up offences. 'Powers derived from public order-related legislation, for example, can address activity which contributes to stirring up racial or religious hatred or hatred on grounds of sexual orientation. ${ }^{34}$ The implication here (so defenders of the anti-terrorism explanation might argue) is that the Conservative government views the stirring up of hatred as part of government policy to prevent terrorism rather than policy to promote integration.

The anti-terrorism explanation faces some not insignificant problems, however. One problem concerns the idea that the Labour government's attempt to introduce new stirring up religious hatred offences via the Anti-Terrorism, Crime and Security Bill in 2001 revealed something of the true purpose of those offences. One problem with this idea is that the Labour Government made no appeal to security issues during 
the key House of Commons debates. Thus, in the second reading debate in the Commons the then Home Secretary, David Blunkett, explained the rationale behind the new offence in terms of responding to requests from Muslim leaders and achieving parity of protection among Jews, Muslims, Sikhs and Christians alike. ${ }^{35}$

Now it is also true that in his comments Blunkett made the following additional argument.

It has been suggested - I heard people say this as recently as this morning on the radio - that it might be used against Muslims. That is true; it might, because Muslims are no less subject to the law than Christians, Hindus, Jews or anyone else. ${ }^{36}$

What this tells us about the underlying purpose of the legislation is open to interpretation, however. Conceivably Blunkett was making an implicit admission that the government really did intend the legislation as a way to help the police fight extremist Islamist ideology and terrorism. But this interpretation could also smack of historical revisionism. At the time several journalists, community leaders and to some extent the wider public were concerned that history could repeat itself in the sense that some of the early successful prosecutions under the Race Relations Act 1965 were against black people. ${ }^{37}$ Blunkett's response was to grasp the nettle: to insist that if one does introduce laws banning the stirring up of religious hatred then it is only right that these laws are applied to everyone. Then again, those who favour the anti-terrorism explanation might simply say that Blunkett was using arguments about equity in the application of law simply as a smokescreen. Admitting that the new offences might also be used against Muslims was a way of preparing the public for the fact that the police would target their use of the laws particularly against extremist Islamist speakers, the real function of the laws. But this interpretation faces a dilemma. On the one hand, if the chief purpose was anti-terrorism and tackling extremist Islamist speakers, why did Blunkett not explicitly mention this intention at the time? On the other hand, if this was the chief purpose but nevertheless Blunkett took the view that it was more strategic not to reveal this purpose to the public, why say anything about Muslims at all? Why draw attention to a purpose that he wanted to remain hidden?

Now it is also true that during the House of Lords debate on the Racial and Religious Hatred Bill in October 2005 Lord Ahmed, a Labour member, declared, 'My 
Lords, the Bill is intended to give faith communities the levels of safety and security to which they are entitled in a diverse, civilised and democratic society. ${ }^{38}$ However, there is reason to think that he meant 'safety and security' in the public order sense rather than in the security and terrorism sense. During the House of Lords debate on the Anti-Terrorism, Crime and Security Bill in November 2001, for example, Lord Ahmed had himself argued that the inclusion of the new offence within an antiterrorism law was not merely a red-hearing but could unwittingly create a pernicious association in the minds of people about terrorism and religion that ought to be avoided. In his words:

The British Muslims are wary that they will be segregated from society because of their religious beliefs, especially in the light of recent world events. If we are to include religion under the same umbrella as terrorism, then it is inevitable that some people may consider certain religious beliefs to be a form of terrorism. We do not want to see that happen. While I strongly support religious discrimination laws, I propose that that should be a separate Bill. This is necessary to avoid any misunderstanding between the two issues and to emphasise that the Government are wholly supportive of the need to improve religious relations. ${ }^{39}$

In a similar vein, Lord Dholakia suggested to his colleagues during the same debate that even the coincidental inclusion of new stirring up religious hatred offences with an anti-terrorism law could potentially undermine an important distinction.

There is also concern about the security of all communities in Britain. The Government have rightly recognised that, but they have done so in the wrong context. Religious hatred, particularly when it is directed at minorities, has existed from the time when minorities set foot in this country. The events of 11th September are not required to recognise that. We on these Benches find it difficult to accept that the Bill is the right place for such legislation. We are not alone in that - even the Commission for Racial Equality argues that a distinction can be made between anti-terrorism measures that can be justified as necessary in the current emergency situation and those that have wider implications and which should be given greater consideration in Parliament. ${ }^{40}$ 
Thus, not only did the Labour government make no appeal to terrorism and national security issues when attempting to introduce the new stirring up religious hatred offences in the immediate aftermath of $9 / 11$ but also the House of Lords successfully removed the new offence from the Anti-Terrorism, Crime and Security Bill at that time partly because several peers argued persuasively that the new offence clearly could not be appropriately considered an anti-terrorism measure.

A second problem has to do with the fact that around the time that the Labour government was finally able to introduce the new stirring up religious hatred offences through the Racial and Religious Hatred Act 2006 it also introduced other offences the stated purpose of which was made explicit, to clamp down on so-called preachers of hate. Charles Clarke pushed through the Terrorism Bill in 2006, which, amongst other things, introduced new encouragement of terrorism and glorification of terrorism offences. The wider context was that the Labour government had been criticised over the failure of police to immediately arrest Muslim demonstrators who, in response to cartoons mocking the Prophet Mohammed published in a Danish newspaper, had, in February 2006, marched through London and stood in front of the Danish embassy wielding placards, amongst other things, praising the 7/7 bombings and calling for beheadings. Clarke was unequivocal about the point of introducing the new encouragement of terrorism and glorification of terrorism offences.

The Government believes that the glorification of terror is an essential - I emphasise that word - method that is used by individuals and organisations that pursue terrorist ambitions and wish to get individuals such as the $7 / 7$ bombers to commit to their suicidal and destructive ends. ${ }^{41}$

That the Labour government introduced in 2006 bespoke offences to deal directly with so-called preachers of hate casts doubt on an interpretation that says the stirring up religious offences, introduced around the same time, were also principally aimed at curbing the activities of extremist Islamist speakers.

A third problem is that if the government wanted to introduce new stirring up religious hatred offences under the banner of anti-terrorism, why did it choose to introduce the offences within the existing framework of public order legislation? Why not insert the offences into other, anti-terrorism legislation? After all, the courts, 
whose job it is to implement the new offences, were always likely to take their lead from the fact that government was amending the Public Order Act 1986, a piece of public order legislation. Now it is certainly true that in some cases involving the new stirring up religious hatred offences courts have used the discourse of security and anti-terrorism in their sentencing remarks. But in other cases the courts have treated the problems being tackled by the offences as public order problems. Consider once again Singh. In her sentencing remarks Judge Dean gave no hint that the offences were being used to address issues of security and terrorism, as evidenced by the fact that the words 'security' and 'terrorism' simply do not figure in the sentencing remarks. In this case the stirring up religious hatred offences - public order offences in legal doctrine or classification - were being used to tackle a local ethno-religious public order problem.

A final problem relates to the anti-terrorism explanation not as an explanation of the Racial and Religious Hatred Act 2006 as such but as an explanation of the ongoing point and purpose of the stirring up religious hatred offences in England and Wales. It has to do with the above-discussed combining, within the discourse of some politicians, of statements about anti-terrorism measures with statements about the stirring up of hatred, especially in relation to iterations of the Prevent Strategy. The anti-terrorism explanation takes this correlation at face value, as telling us something about the shared purpose of encouragement of terrorism and glorification of terrorism offences, on the one hand, and stirring up hatred offences, on the other. But this explanation belies the nuanced nature of the correlation. For example, speaking in November 2014 about the Conservative government's anti-terrorism measures, Theresa May stated:

Since I became Home Secretary, I have excluded hundreds of people in total from Britain. I have excluded 61 people on national security grounds and 72 people because their presence here would not have been conducive to the public good. In total, I have excluded eighty-four hate preachers. ${ }^{42}$

Perhaps insufficient care is taken here to make the point that some "hate preachers" were excluded on national security grounds whereas other "hate preachers" were excluded because their presence here would not have been conducive to the public good, such as if they posed a risk to public order, say. But nevertheless the fact that 
these two grounds for exclusion are separated gives a strong indication that the real function, as well as the actual practice, of immigration rules allowing the Home Secretary to exclude people who stir up hatred, cannot be exclusively related to the prevention of terrorism. Put crudely, if 61 people were excluded on national security grounds but 84 "hate preachers" were excluded, it stands to reason that at least some "hate preachers" must have been excluded for reasons other than national security.

\section{The client politics explanation}

Yet another explanation appeals to the idea of client politics. ${ }^{43}$ Put crudely, a client politics approach to explaining the introduction of new stirring up religious hatred offences back in 2006 highlights the patterns of benefits and burdens faced by different groups in society as a predictor of changes in legislation serving or not serving the interests of those groups. Where the stirring up of religious hatred, and the burdens associated with the climates of hatred and fear to which this sort of speech contributes, is concentrated on a particular group, one can expect that group to be more likely to mobilise to request laws that offer some protection against this hate speech than is the case if the burdens are dispersed across society. On this explanation, the basic reason why we ended up with new stirring up religious hatred offences was the fact that Muslim groups were being disproportionately burdened by this sort of hate speech. Indeed, the client politics explanation is also consistent with the putative fact that the introduction of new stirring up religious hatred offences happened at a time when there was an increase in the stirring up of hatred against Muslims in the wake of after high-profile extremist Islamist terror attacks.

It can be pointed out, in support of this explanation, that although the new stirring up religious hatred offences would also provide protection to Christians, Hindus, and Buddhists, for instance, most of the debate in public life concentrated on Muslims. So, for example, as early as 2003 the House of Lords Select Committee on Religious Offences in England and Wales recognised that the government's proposal to introduce new stirring up religious hatred offences via the Anti-Terrorism, Crime and Security Bill in 2001 'proceeded from threats to the Muslim communities and their members, following the events of 11th September 2001 in New York, and other acts 
of terrorism elsewhere. ${ }^{44}$ And, in the words of David Blunkett during the House of Commons debate on the Anti-Terrorism, Crime and Security Bill in November 2001:

We were approached by leaders of the Muslim community - it was a representative leadership group - who thought that it was only right, fair and protective to include religion with race in terms of avoiding incitement to hate using the Public Order Act 1986. I considered that and decided that their point was fair and reasonable. ${ }^{45}$

Subsequently, in a speech to the Institute of Public Policy Research in July 2004 Blunkett stated that '[i]f anything the arguments for this extension of the law have grown stronger since $2001, \cdot{ }^{46} \mathrm{He}$ did not on that occasion pause to explain why the argument had 'grown stronger', but it may be plausible to read this statement as a response to civil society research being undertaken at the time on the rise of islamophobia since 2001. Take, for instance, a report by the independent Commission on British Muslims and Islamophobia in June 2004 setting out the impact of 9/11 and the ensuing wars in Afghanistan and Iraq on the experiences of British Muslims, including experiences of anti-Muslim hostility and its manifestation in verbal as well as physical attacks on Muslims in public places. ${ }^{47}$

A central claim of the client politics explanation is that if the burdens of the stirring up of religious hatred are disproportionately imposed on a particular group rather than being spread evenly across society, one can explain and would expect the affected groups to lobby governments to bring about legislation even at the expense of the interests of the general public. Putting this another way, even if the relevant incitement to hatred laws are not in the interests of the general public (e.g., speaker and audience interests in free public discourse on matters concerning religious believers as well as religious beliefs), minority religious groups would be acutely aware of the cost of other people enjoying the freedom to stir up hatred against them and so would be particularly motivated to persuade politicians to legislate. In that sense the real function of, and true explanation for, the new stirring up religious hatred offences was to serve the interests of Muslim clients and thereby to serve the interests of politicians standing for election in constituency containing these clients.

Two factual premises need to be substantiated, therefore. The first is that Muslims did lobby the government for a change in the law. This premise seems entirely 
unproblematic. The evidence suggests, not least from the testimony of parliamentarians, that a many Muslim groups and leaders did assert that they were suffering from an increase in hate speech post $9 / 11$ and 7/7 and did lobby their MPs and the government for new stirring up religious hatred offences as part of the solution. Of course, it is also the case that some Muslims argued against the introduction of the new offences precisely because they seemed to be another way of putting Muslims to the forefront of the public's consciousness, and not in a good way. But this need not in itself undermine the client politics explanation. It is enough that some Muslim groups did mobilise in favour of the legislation because it represented a net benefit to them.

The second premise is that this lobbying resulted from the facts on the ground. For the client politics explanation to work it must actually be the case that there was a disproportionate burden of incitement to hatred on a particular group (Muslims), as well as a concentrated benefit to be had from legal protection also for that group, with costs in freedom expression diffusely distributed across the general population. With regards to this premise, however, the main problem for the client politics explanation is a lack of tailored evidence. Official hate crime statistics, in the form released to the public, tend to be broken down by broad categories, including religion, but not disaggregated into particular religions. From time to time supplementary official reports are released which do provide this level of information. For example, in its 2012 report Anti-Muslim Hate Crime: Learning From Casework, the CPS stated that '[t] he majority of the religiously aggravated hate crime cases sampled (62\%) involved an element of anti-Muslim sentiment'. ${ }^{48}$ Similarly, in its 2013 report An Overview of Hate Crime in England and Wales the Home Office, Office for National Statistics and Ministry of Justice stated that 'the 2011/12 and 2012/13 '[the Crime Survey for England and Wales] showed that Muslim adults were the most likely to be a victim of religiously motivated hate crime ${ }^{49}$ So in theory one could postulate for the purposes of the explanation that these figures would not have changed significantly from around 2005-6. Nevertheless, although these statistics are broken down by broad category of offence, such as public order offences, they are not broken down by specific type of offence, such as a particular public order offence. This means that even hate crime statistics on religiously motivated public order hate crimes will typically include public order hate crimes that are not essentially speech-based, public order hate crimes that are speech-based but are not the stirring up offences, and, 
finally, the stirring up hatred offences. ${ }^{50}$ So it is quite possible that both hate crime statistics and the experiences of those Muslims who lobbied the government were based on a blurring of different kinds of incidents involving islamophobic hate speech. It is quite possible that what Muslims were actually experiencing was an increase in the incidence of the religiously motivated public order offence of intentional harassment, alarm or distress - for example, person A, who is nonMuslim, uses threatening, abusive or insulting words or behaviour or displays a sign that is threatening, abusive or insulting, with intent to cause harassment, alarm or distress and thereby caused harassment, alarm or distress to person B who was Muslim or perceived to be Muslim, aggravated by religious hostility. ${ }^{51}$ But not necessarily an increase in the incidence of the stirring up of religious hatred - for example, person A, who is non-Muslim, uses threatening words or behaviour with the intention of stirring up hatred against Muslims, perhaps to an audience of fellow nonMuslims. Of course, none of this proves that Muslims did not suffer a burden of increased incidence of the stirring up of religious hatred against them post 9/11 and 7/7. But nevertheless the client politics explanation runs hollow if the disproportionate burden premise cannot be substantiated with evidence.

Now it might be pointed out at this stage that non-governmental organisations are also a source of tailored information about hate crimes. Tell MAMA, for example, provides self-identifying victims or witnesses of hate crimes and incidents an opportunity to self-report their experiences, and provides annual data on self-reports of anti-Muslim hate crimes and incidents. In 2014 academic researchers from the Centre for Fascist, Anti-Fascist and Post-Fascist Studies at Teesside University conducted a study of the methods and findings of Tell MAMA and found that '[w]ithstanding the necessary caveats of self-reported data $[\ldots]-$ now minimised as far as possible by the tightening of data collection processes - the data collected by Tell MAMA is reliable. ${ }^{52}$ Both in the Tell MAMA annual reports investigated by Teesside University, and in Tell MAMA's subsequent annual reports, the organisation identifies a clear correlation in the data: namely, spikes in the rate of self-reports of anti-Muslim hate crimes and incidents after high profile public events involving Islamistist extremism, such as after the killing of Lee Rigby, the Charlie Hebdo attack in Paris, the story of three Muslim schoolgirls leaving Britain to join ISIS, the attack in the tourist resort in Tunisia, and the November 2015 Paris attacks. ${ }^{53}$ Once again, perhaps one could postulate that spikes that are in evidence now would have also 
occurred back in 2001 after $9 / 11$ and in 2005 after the 7/7 London bombings. However, there remains a difficulty with the Tell MAMA data coding, at least as far as the client politics explanation is concerned. Tell MAMA caseworkers sub-divide self-reported anti-Muslim hate crimes and incidents as follows: for online incidents, the categories are 'abuse', 'anti-Muslim literature' and 'threat'; for offline incidents, they are 'property damage', 'assault', 'threat', 'extreme violence' and 'anti-Muslim literature' ${ }^{54}$ But it cannot just be assumed that reports coded as 'threat' and 'antiMuslim literature' together amount to the use of threatening words or behaviour with the intention of stirring up of hatred against Muslims. Even if this is an imperfect, but workable proxy, there is also the problem of comparing this data, which focuses exclusively on Muslims, with the situation faced by other religious groups. If there is no comparable data on the extent of incitement to hatred against, say, Jews, Sikhs, Hindus, for example, or indeed, against the LGBT community or people with disabilities, the premise that Muslims were disproportionately burdened by incitement to hatred cannot vindicated. Then, of course, there is the problem that the data does not extend back to 2001 and 2005 .

It might be tempting at this stage, therefore, to see if the case law can provide falsifying or corroborating evidence for the client politics explanation. But once again this evidence is inconclusive. If Muslims really were being disproportionately burdened by the stirring up of hatred, then, other things remaining equal, one might have expected to see a slew of convictions for people stirring up religious hatred against Muslims once the Racial and Religious Hatred Act 2006 came into force. But this did not happen. This author knows of only one such example, Singh. Compare the situation with the steady stream of convictions for the stirring up of racial hatred against Jews, for example. I have already mentioned $R$. v. Iftikhar Ali, R. v. Hamza, R. v. Rahman, R. v. Javed, and R. v. Saleem. To this list one can also add $R$. $v$. Birdwood, ${ }^{55}$ R. v. Atkinson, Piggins, Hill, Bostock, and Denis, ${ }^{56}$ R. v. Sheppard and Whittle, ${ }^{57}$ R. v. Heaton and Hannington, ${ }^{58}$ and R. v. Bonehill-Paine. ${ }^{59}$ On the other hand, it is clear that other things are not equal, meaning that other factors might explain the disparity. One is the willingness of members of different religious communities to report cases to the police. Another, more important factor is that the basic elements of the stirring up religious hatred offences are importantly different to the stirring up racial hatred offences. When it comes to the former offences, the legislation includes the intention clause, the threatening language clause, and the 
Freedom of Expression clause - all of which have set the bar for successful prosecution so high that very few cases can pass muster. But when it comes to the latter offences, the test is intention or likelihood, threatening, abusive or insulting language, and no freedom of expression clause - all of which makes for a greater number of prosecutable cases, albeit still relatively few compared to other public order offences. ${ }^{60}$ It is also relevant here that the Freedom of Expression clause ${ }^{61}$ was introduced by the Lords, not by the government. The government took that view that the legislation offered adequate protections of free speech already, and so the clause was redundant. But the government did not succeed in overturning the Lords amendment in the commons. In short, the will of the government and the will of the Houses of Parliament pointed in different directions and the government did not get its way. ${ }^{62}$ All of these mitigating factors working together could mean that the client politics explanation is not undermined by the low conviction rates, after all.

Since the hate crime statistics and the case law neither establishes nor discredits the premise that Muslims were disproportionately burdened with incitement to hatred, however, it does remain a possibility that at the time Muslims were merely one group among many others who experienced a similar burden from incitement to hatred. In fact, some other relevant evidence points to exactly this situation. If the burden of incitement to hatred was actually diffusely distributed among numerous minority groups, then this suggest that numerous, well-organised interest groups would be motivated to persuade the government to adopt a much broader strategy on tackling the stirring up of hatred, such as by enacting legislation that banned the stirring up of hatred on the basis of a long list of protected characteristics. This is precisely what happened. At the time of the Racial and Religious Hatred Bill 2005, some gay rights campaigners were also calling on government to extend the stirring up hatred offences to include sexual orientation as well as religion. Some Liberal Democrat MPs were making similar suggestions in the 2005 General Election. This public influence was also clearly reflected in the parliamentary exchanges on the Racial and Religious Hatred Bill, where sexual orientation was also discussed and the case made for its inclusion. ${ }^{63}$ Likewise, only a year after the Racial and Religious Hatred Act 2006, the leading gay rights interest group, Stonewall, presented its argument for new offences covering sexual orientation during the Committee Stage of Criminal Justice and Immigration Bill in 2007. ${ }^{64}$ (In fact, there are signs that this is now starting to happen with disability. Consider the recent electronic petition calling on the government to 
extend the stirring up hatred offences to cover disability. ${ }^{65}$ ) That Muslims were not alone in pushing for protection contradicts the client politics explanation. Instead, it points toward something like an umbrella of interest groups explanation. ${ }^{66}$

\section{The parity of protection explanation}

This final explanation of the government's introduction of the stirring up religious hatred offences builds on the client politics narrative about Muslims being in an especially difficult situation, but redirects that narrative towards the more basic point that Jews and Sikhs did, but Muslims did not, enjoy protect against the stirring up of racial hatred under the Public Order Act 1986, due to the way courts in England and Wales interpreted the meaning of the words 'race' and 'ethnicity'. According to this explanation, the real function of the Racial and Religious Hatred Act 2006 was simply to achieve parity of protection for similar groups, quite apart from whether or not Muslims were in fact disproportionately burdened by incitement to hatred.

According to the parity of protection explanation, the key turning point for an eventual change in the law can also be traced back to 1998 when the Runnymede Trust launched its Commission on the Future of Multi-Ethnic Britain (funded by the Joseph Rowntree Charitable Trust). Following the landslide victory of the Labour Party in the 1997 general election, the new Home Secretary and MP for Blackburn (another northern British town with a significant South Asian population and one of the highest proportions of Muslims in the country), Jack Straw, attended the launch event on behalf of the government. In October 2000, the Commission, now chaired by the scholar of British identity and multiculturalism, Bhikhu Parekh, published its report. At the time The Telegraph published a series of critical responses to the Parekh Report, falsely accusing it of declaring the term "British" a 'racist' term. Jack Straw sought to partially distance the Labour government from what was being portrayed in the media as the extreme multiculturalist ideology of the Parekh Report. Nevertheless, in the Report the Commission briefly touched on the problem of incitement to hatred. It made two crucial points: first, that the European Convention on Human Rights (ECHR) itself provided a broad framework for a new settlement between the diverse racial, ethnic and religious communities of Britain, including a balance between 'the right to free speech and the right to freedom from incitement to 
racial hatred'; ${ }^{67}$ second, that Jews in Britain had benefited from the strengthening of countervailing forces against anti-Semitism, including laws banning the stirring up of hatred on grounds of race, ethnicity and national origin, but also that '[i]t would be perverse [...] not to acknowledge that, however deeply wounding and painful expressions of antisemitism are in Britain today, the racism experienced by Asian, black, Gypsy and Irish communities demands primary attention. ${ }^{68}$ The Parekh Report was a high water mark of a type of public intellectual work on multiculturalism which enjoyed the ear of the Labour government. On the issue of stirring up religious hatred, its ideas echoed recommendations that had also been made back in 1992 by the Commission for Racial Equality in its Second Review of the Race Relations Act 1976: namely, that the government should introduce new stirring up religious hatred offences. ${ }^{69}$ The Commission for Racial Equality's Review spoke of the doubly 'anomalous' situation that whilst Jews and Sikhs (in the wake of Mandla v. Dowell$L e e^{70}$ ) but not Muslims enjoyed protection against the stirring up of racial hatred in England and Wales, in Northern Ireland the law covered race and religion, and so Jews, Sikhs, Muslims, Christians and Hindus alike. ${ }^{71}$ Together these commissions seemed to have cleared a pathway for a change in the law, removing obstacles that had been laid down by Dingle Mackintosh Foot back in 1965. They addressing concerns over free speech and they motivated the necessity of the legislation to address lack of parity.

Evidence for the parity of protection explanation is also not hard to find in the relevant parliamentary debates of 2005. Consider the words of Charles Clarke during the second reading debate on the Racial and Religious Hatred Bill in the House of Commons in June 2005.

The Bill seeks to address the anomaly that means that Jews and Sikhs are protected under the existing law, but that other faith groups, and people of no faith, are not protected. I think that that is simply not right and that the problem needs to be addressed. ${ }^{72}$

It is also appropriate to consider some of the arguments made in the House of Lords, who in the end would not oppose the Racial and Religious Hatred Bill once the Freedom of Expression clause had been added. During a House of Lords debate in October 2005, for example, several Lords defended the Bill on grounds of parity. 
Lord Ahmed said: 'Put simply, it is about preventing people inciting hatred and providing all communities with equal protection. ${ }^{73}$ Or, as Baroness Ramsay put it, the provision will 'remove the anomaly whereby mono-ethnic faith groups such as Sikhs and Jews are protected under the incitement to racial hatred provision, whereas multi-ethnic groups, such as Muslims and Christians, are not. ${ }^{74}$ Lord Avebury then offered up the following example of the anomaly at work in English courts.

A cleric who urged followers to kill non-believers, Americans, Hindus and Jews was jailed, first, for seven years for incitement to commit murder, and then an extra two years were added for incitement to racial hatred. If he had chosen his words more carefully and excluded Jews from this incitement, he would have been given only seven years and not nine. ${ }^{75}$

Although Lord Avebury did not specify, it is highly likely from his description of the case and the sentence handed down that he was referring to El-Faisal.

Another potential advantage of the parity of protection explanation is that it can point to a coherent strategy pursued by the government in dealing with issues of religion and hatred. After all, the Labour government back in 2001, via the AntiTerrorism, Crime and Security Act 2001 (s. 39), successfully amended existing hate crime legislation (the Crime and Disorder Act 1998), so as to include sentenceenhancement provisions for offences that are racially or religiously aggravated. This was an omnibus act which included both hate crime and anti-terrorism measures. But the legislative intention was, arguably, transparent: namely, to achieve parity of protection for victims of hate crime. The aim of removing the anomaly of unequal protection against hate crimes across all faith communities in England and Wales could be seen in the arguments put forth by various Lords during debates. ${ }^{76}$ Significantly, this policy also had a bearing on instances of hate speech covered by public order offences other than the stirring up of racial hatred offence. Consider cases of religiously aggravated harassment, alarm or distress, ${ }^{77}$ such as Norwood $v$. $D P P,{ }^{78}$ in which the defendant displayed a poster that read 'Muslims out of Britain'.

The parity of protection explanation might also be used to explain further extensions of the stirring up hatred family of offences to other groups. In 2007, for example, during the second reading debate on the Criminal Justice and Immigration Bill, Chris Bryant declared that it was high time to introduce an offence of stirring up 
hatred on grounds of sexual orientation in order to 'overcome anomalies' in the relevant laws. ${ }^{79}$ Likewise, in 2011 the Equality and Human Rights Commission defended the creation of a new offence of stirring up hatred on grounds of disability for the sake of 'parity' ${ }^{80}$ More recently, a significant number of the individuals and stakeholder organisations who took part in the Law Commission's consultation exercise allied to its report, Hate Crime: Should the Current Offences be Extended?, argued on the basis of parity for the creation of new stirring up hatred offences for both disability and transgender identity. ${ }^{81}$ The Commission itself ultimately did not recommend this extension for mainly practical reasons (they took the view that there was insufficient evidence that the kind of conduct that would be caught by the act is actually occurring). However, in 2015 the House of Commons Women and Equalities Committee also heard evidence from a number of expert witnesses on the need for parity of protection for people with transgender identities given facts on the ground. ${ }^{82}$ Pace the Law Commission, the Women and Equalities Committee recommended that ' $[\mathrm{t}]$ he Government should introduce new hate crime legislation which extends the existing provisions on [...] stirring up hatred so that they apply to all protected characteristics, as defined for the purposes of the Equality Act 2010. ${ }^{83}$

Nevertheless, I must also address four potential problems even with the parity of protection explanation. One problem is that by itself the explanation may struggle to explain why politicians and peers accepted the introduction of the new stirring up religious hatred offences as the appropriate response to anomalies in the protection of groups. The parity of protection explanation highlights the fact that courts in England and Wales have on occasions convicted radical Muslim clerics or extremist Islamist activists for inciting racial hatred against Jews - for example, Iftikhar Ali and ElFaisal - but at the same time the courts have not regarded Muslims as belonging to a racial, ethnic or national group for the purposes of interpreting the stirring up racial hatred offence - a view consistent with a leading case in the field of antidiscrimination law, Nyazi v. Rymans Ltd $^{84}$ And so, in 2005 a rabbi could not be convicted for stirring up racial hatred against Muslims. Yet, it would have been perfectly consistent with the principle of parity of protection to remove the protections offered to Jews and Sikhs by repealing s. 3 of the Public Order Act 1986, say, as opposed to retaining those protections and extending them to Muslims via s. $3 \mathrm{~A} .{ }^{85}$

A second problem is that even if the parity of protection explanation can account for the introduction of new stirring up hatred offences covering religion and sexual 
orientation, it does not at the present time seem to be a basis for making safe bets about the introduction of yet further offences covering transgender identity and disability, still less age or physical appearance. For example, in July 2016 the government published its long awaited plan for addressing the problem of hate crime, Action Against Hate: The UK Government's Plan for Tackling Hate Crime. In response to recommendations from disability rights groups, academics including myself, and the Women and Equalities Select Committee, that the existing stirring up hatred offences should be extended to cover transgender identity and disability, the government's new plan of action is to take no action. That is, '[g]overnment will consider these [recommendations]. ${ }^{86}$ In fact, the government had already been considering these recommendations (or kicking them into the long grass) since the Law Commission recommended against extending the stirring up hatred offences back in $2014 .{ }^{87}$ Not merely the Conservative government but parliament as a whole seems ambivalent at best about the extension project. At first blush, this might seem difficult to square with the idea that what tends to drive the introduction of new stirring up hatred offences is a concern with parity of protection.

A third problem is that at least in 2005 the government had permitted other anomalies in the area of free speech and religion to continue - not least blasphemy laws protecting Christians but not Jews, Muslims, Sikhs, or Hindus, for example. So if the government's core motivation when dealing with these policy issues really was to provide parity, then why did it allow uneven protection on this other matter? ${ }^{88}$

Finally, the parity of protection explanation cannot explain why the stirring up racial hatred offence was introduced in the first place.

No doubt it is easier to reply to some of these problems than to others. The point about blasphemy laws, for example, is straightforwardly undercut by the fact that the Labour government fairly swiftly moved to also abolish common-law offences of blasphemy and blasphemous libel in England and Wales via the Criminal Justice and Immigration Act 2008. The other problems are trickier.

Nevertheless, the problem about the anomaly being resolved through repeal rather than extension might be countered by saying that although the real driving force is a concern for parity of protection, that principle itself is likely to be embedded in a deeper principle of good administration, whereby governments seek higher-order consistency in the enactment of criminal law, that is, the principle of treating like reasons alike (and unalike reasons unalike). For example, one possible reason for 
banning incitement to racial hatred is that certain kinds of racist hate speech can contribute to climates of hatred and fear. Applying this same rationale to the case of Muslims could justify the course of action of extending hate speech law to cover religion, based on a parallel concern that stirring up hatred against Muslims can contribute to climates of hatred and fear, rather than the course of action of repealing law. ${ }^{89}$ Alternatively, it might be that concern for parity of protection is actually derivative of a commitment to a more fundamental principle of showing equal respect for the ethnic and cultural identities of all human beings. ${ }^{90}$ This would certainly chime with other aspects of the multiculturalist vision set out in the Parekh Report 2000, assuming that the Report either echoed or influenced the Labour government's thinking.

The point about the Conservative government's failure to extend the stirring up offences still further in the name of parity can also be countered as follows. Just because history tells us that when extensions of the stirring up hatred offences have occurred they have probably been driven by parity of protection; it does not mean that whenever parity of protection considerations are in play, then inevitably new extensions occur. Legislative change does not work like that. There are innumerable forces blocking the introduction of new legislation at any given time. The government is focused on Brexit at present; and it is considering a new British Bill of Rights. The latter especially would need to be dealt with as part of considering any further limits on free speech. This is in addition to the government's contention that there is insufficient evidence of a serious problem of incitement to hatred on grounds of transgender identity or disability. So the parity of protection explanation cannot be expected to forecast future extensions even if it can explain past extensions. Or, if the explanation can make forecasts, maybe these need to be framed in the longer term, thus controlling for other variables.

Or perhaps the parity of protection explanation needs to be combined with other explanations in order to explain why future extensions have not occurred. In any event, it will need to be augmented with other explanations in order to explain why the stirring up racial hatred offences were introduced in the first place.

Following on from this, it seems to me that surely the correct response to these problems, and the best approach full stop, is to explain the real function, and true explanation for, the new stirring up religious hatred offences in a pluralistic way. 


\section{A pluralistic explanation}

A pluralistic explanation of the rise and purpose of the stirring up religious hatred offences proceeds on the basis that there is nothing inconsistent in explaining the original creation of the stirring up racial hatred offences in one way, explaining the stirring up religious hatred offences in a different, more complex way, and explaining the failure of government to introduce yet more stirring up hatred offences in another way again.

The pluralistic explanation might run thusly. First, a significant part of the impetus for the creation of the stirring up racial hatred offences was ethnic tensions and race riots following a period increased immigration (the public order explanation).

Second, the Labour government introduced the stirring up religious hatred offences partly because it had concerns about public order in the wake of increasingly complex racial, ethnic and religious mass disturbances and riots (the public order explanation). Another part had to do with how Muslims, in particular, had mobilised as lobbyists, not necessarily because they were disproportionately burdened by hate speech, but instead because of an acute awareness that they did not enjoy the same legal protections as other groups (the client politics explanation combined with the parity of protection explanation). In other words, the relevant burden partly consisted in the fact that Muslims were being treated, and believed that they were being treated, as second-class citizens by the law. Consider, once again, the letter that was allegedly sent by the office of Charles Clarke to several mosques in 2005. The letter includes the statement, '[w]e cannot see why it is right to have protection in law for Jews and Sikhs, but wrong to extend it to other communities like the Muslim community.' This foreshadows what Charles Clarke said in parliament on the matter. But it is also important to understand that the letter was on Labour Party headed paper, around election time, explicitly laying blame at the door of members of the Liberal Democrats Party and the Conservative Party for the removal of the stirring up religious hatred offences from Serious Organised Crime and Police Bill. So in that sense the letter - assuming it did exist, and was in fact sent to mosques - was making an appeal to Muslim clients. But the crucial point here is that the burden it acknowledged was not an increase in anti-Muslim hate speech post 9/11 but instead 
an appreciation that Muslims were being treated differently than Jews and Sikhs when it came to legal protections against the stirring up of hatred (the client politics explanation combined with the parity of protection explanation).

Third, when questions emerge about why other stirring up hatred offences have yet to be introduced, such as for transgender identity and disability, these questions require complex answers. It is may be true that currently the burden of incitement to hatred is diffusely distributed among numerous minority groups, and this has created a number of interest groups seeking further extensions of the stirring up hatred offences (the umbrella of interest groups explanation). And it may also be true that the government is inclined to want to undo anomalies in the cover provided by the existing offences (the parity of protection explanation). However, actual mass disturbances and riots in England and Wales have not evolved, yet, to include dimensions relating to transgender identity and disability (the public order explanation), and various other factors relating to Brexit mean that the government's attention is currently taken up elsewhere (endogenous explanations).

\section{Implications}

I have argued that the best explanation not merely of why we ended up with the Racial and Religious Hatred Act 2006 but also the ongoing point and purpose of the stirring up hatred offences is likely to be pluralistic, and that our understanding is hindered rather than helped by the terrorisation of these offences, so to speak. In this section I want to briefly explore the implications of this conclusion for normative debates about hate speech laws and freedom of expression going forward.

The main point I want to make is that it matters what types of normative arguments academics and others are presenting to governments about why they should retain the stirring up hatred offences or even extend them further. The wrong types of arguments are those which are in tension with the best explanations of governmental intentions in this field of policymaking, potentially making them doomed to failure. Of course, one possible response to the tension is simply to deny that it matters: the right arguments are the right arguments and so it is up to those people who believe that the stirring up hatred offences should be extended, say, to convince governments to embrace their way of thinking. A second response, to which 
I more sympathetic, is that legal and political theorists, if they want to change the world, have every reason, when presenting normative arguments to governments, to present whichever, already good arguments best match the government's way of thinking.

So what normative arguments could potentially play well with the Conservative government on the issue of extending the stirring up hatred offences to include transgender identity and disability? Predictably, one potential argument would emphasise people's right to parity of protection. Put simply, if two similar groups of people are subject to similar forms of incitement to hatred, but one of the groups enjoys legal protections against such speech whereas the other group does not, then the other group has a prima facie right to similar protection also. ${ }^{91}$ As Alon Harel puts it, 'treating the victims of racist speech more favorably than victims of sexist, homophobic, or other forms of abhorrent speech is itself a form of discrimination. ${ }^{92}$

Another potentially important argument combines the right to parity of protection with an argument based on the public assurance of civic dignity. According to Jeremy Waldron, certain sorts of group libel and incitement to hatred laws could be warranted if they help to protect people's sense that they are members of society in good standing, the sort of assurance that can be undone when they are confronted by public hate speech which downgrades or denigrates them. ${ }^{93}$ It strikes me that the threat to assurance could be especially high where certain groups realise that they lack the legal protections against incitement to hatred that other groups enjoy. If people with transgender identities or disabilities, for example, see that they lack the legal protections that various faith communities and gays and lesbians have benefited from, then this may compound the harmful effects of the incitement to hatred they endure. Both the incitement to hatred and the failure of parliament to act against it could leave people with transgender identities or disabilities feeling that they are second-class citizens. In other words, lack of parity of protection could be particularly devastating for their sense of assurance that they are members of society in good standing. ${ }^{94}$

However, anyone who wants to persuade the government to extend the stirring up hatred offences must also clear away barriers that the government currently recognises, as previous governments have recognised, for not extending these offences. First among these barriers is freedom of expression. Examples of laws banning incitement to hatred can be found not just in England and Wales but also in domestic penal codes and various other legal instruments in countries across the 
globe. ${ }^{95}$ Yet these laws continue to be subject to fierce criticism, especially, although not exclusively, among US scholars who defend freedom of expression based on values of autonomy, democracy and legitimate government. ${ }^{96}$ (Note, laws banning incitement to hatred cannot be found at either the federal or state levels in the US due to the way in which courts have interpreted the First Amendment over the past half century.) When the Labour government introduced the Racial and Religious Hatred Bill in 2005, several legal scholars raised objections, based on what they viewed as inherent differences between race and religion which made the former but not the latter worth of protection under incitement to hatred legislation, and on their perception that the latter posed a special threat to freedom of expression. ${ }^{97}$ Others, myself included, tried to make the counter case for the extension. ${ }^{98}$ Nevertheless, what nearly all sides in this debate agree about is that if a plausible case is going to be made for extending incitement to hatred laws still further, then only the strongest, principled arguments will do; anything less would be easily defeated by principled arguments on the side of free speech.

But what are the strongest arguments? More importantly, are any of the strongest arguments likely to chime with the best explanations of why governments have in the past extended the stirring up hatred offences and why the Conservative government might do so in the future? One potential argument is that laws banning the stirring up of hatred on grounds of transgender identity or disability can be warranted insofar as the stirring up of hatred against these groups contributes to a climate of hatred in which hate crimes are more likely, and to a climate of fear, in which individual members of these groups suffer debilitating fear that they could become the victims of hate crime. ${ }^{99}$ This sort of argument might chime with the umbrella of interest groups explanation. In the event that the burden of incitement to hatred is diffusely distributed among numerous minority groups, including people with transgender identities or disabilities, this could create a number of interest groups seeking further extensions of the stirring up hatred offences. The present argument speaks to the sort of burdens faced by members of these minority groups. It could also be useful to the relevant interest groups in putting their case to government; provided, that is, evidence can be found that substantiates the arguments linking incitement to hatred with climates of hatred and fear and linking those climates with hate crimes, say.

I also do not think that arguments which speak to public order, and therefore, march in step with the public order explanation, are out of the question. No doubt 
defenders of the status quo could react by saying that our society has experienced religious wars and race riots, but not violent public explosions of simmering tensions between cisgender and transgender people, and not rioting by people with disabilities. In other words, it may be that mass disturbances and riots in England and Wales have yet to evolve to include the dimensions of transgender identity and disability, along with the dimensions of race, ethnicity and religion. However, arguably this was also not the case with sexual orientation. Yet the government did not wait for mass disturbances to occur involving violence between religious conservatives and homosexuals, say, before extending the legislation to cover sexual orientation. The risk was enough. This is also borne out in the case law. In R. v. Ali, Javed, and Ahmed, ${ }^{100}$ for example, three Muslim men became the first people to be successfully prosecuted for offences relating to the stirring up of hatred on grounds of sexual orientation in England and Wales. Acting together the men distributed leaflets on the streets of Derby titled 'Turn or Burn', 'GAY - God Abhors You', 'Death Penalty?' as a protest to the Gay Pride Festival taking place that day. In his sentencing remarks Judge Burgess used the language of public order: 'the vast majority of us get along together very well', 'the greatest freedom that we all enjoy is to live in peace and without fear', 'It was clearly perceived by parliament that people of a particular sexual orientation needed protection from that minority who wished to stir up hatred against them', 'your intention was to do great harm in a peaceful community'. ${ }^{101}$ According to a more subtle version of the public order explanation, therefore, the government will, under the right circumstances, introduce laws banning the stirring up of hatred in response to the risk of mass disturbances and riots that have taken on more complex dimensions. So one potentially impactful line of normative argument might be that the stirring up of hatred against people with transgender identities or disabilities has the potential to become tomorrow's Bradford riots, in any parts of the country with significant proportions of such people, and taking a precautionary approach to the avoidance of such public disorder can warrant a change in the law. ${ }^{102}$

\section{Acknowledgments}


I would like to thank Sally Broughton Micova, Charles Clarke, Michael Frazer, Chris Hanretty, and Adriana Sinclair for useful feedback on an early draft. I am also very grateful to the journal's two anonymous reviewers for their insights and suggestions.

\section{Disclosure statement}

No potential conflict of interest was reported by the author.

\section{Notes on contributor}

Alexander Brown is Senior Lecturer in Contemporary Social and Political Theory at the University of East Anglia (UEA). He is the author of Hate Speech Law: A Philosophical Examination (New York: Routledge, 2015).

${ }^{1}$ In response to the Labour government's introduction of the Racial and Religious Hatred Bill in 2005 Lords Lester and Lucas argued in a House of Lords debate that that legal professionals tasked with enforcing laws banning incitement to religious hatred would have an especially hard time distinguishing between speech that stirs up hatred against religious believers and speech that stirs up hatred against religious beliefs (such as through criticism, ridicule and satire). Hansard (HL), October 11, 2005, vol. 674, cols. 173-5 and 203-204. The same worry was expressed by several high-profile writers, actors, and legal commentators. See, e.g., Rowan Atkinson, 'The Opposition's Case', in L. Appignanesi (ed.) Free Expression is No Offence (London: Penguin, 2005); Philip Pullman, "Against "Identity"' in L. Appignanesi (ed.) Free Expression is No Offence (London: Penguin, 2005); Gareth Crossman, 'Religious Hate: A Criminal Offence? Liberty Says No', Legal Action (March) (2005): 9; Joshua Rozenburg, 'Now you face jail for being nasty to Satanists', Daily Telegraph, June 10 (2005). In October 2005 Lords Hunt, Lester, Carey, and Plant succeeded in persuading their colleagues to accept an amendment to the Racial and Religious Hatred Bill that addressed the problem, specifically, by inserting s 29J, 'Protection of freedom of expression: Nothing in this Part shall be read or given effect in a way which prohibits or restricts discussion, criticism or expressions of antipathy, dislike, ridicule, insult or abuse of particular religions or the beliefs or practices of their 
adherents, or of any other belief system or the beliefs or practices of its adherents, or proselytising or urging adherents of a different religion or belief system to cease practising their religion or belief system.'

${ }^{2}$ See, e.g., Peter Cumper and Peter W. Edge 'Muslims, counter-terrorism, and human rights in the United Kingdom', Research Papers, Research Papers, Human Rights Conflict Prevention Centre (HRCPC) 1-2 (2005), 595-616, reprinted in N. Bašić and A. H. Siddiqui (eds.) Rethinking Global Terrorism (Islamabad: International Islamic University Press, 2009); Alan Thornett, 'Racial and Religious Hatred Bill - A Serious Threat to Free Speech', International Viewpoint, November 9 (2005), www.internationalviewpoint.org/spip.php?article903; Shami Chakrabarti, Comments cited in 'Satanists to be protected under Religious Hatred Bill', Times Online, June 9, 2005; Erik Bleich, "Faith and State: British Policy Responses to "Islamist" Extremism', in R. Eatwell and M. Goodwin (ed.) The New Extremism in 21st Century Britain (London: Routledge, 2010), p. 79; The Freedom to Be Racist? How the United States and Europe Struggle to Preserve Freedom and Combat Racism (Oxford: Oxford University Press, 2011), p. 26; Clive Walker, Terrorism and the Law (Oxford: Oxford University Press, 2011), p. 382.

${ }^{3}$ Hansard (HC), May 3, 1965, vol. 711, col. 1043.

${ }^{4}$ Ibid.

${ }^{5}$ For a summary, see Law Commission, Hate Crime: The Case for Extending the Existing Offences, Appendix B: History of Hate Crime Legislation (London: The Stationery Office, 2013), pp. 31-33.

${ }^{6}$ Hansard (HC), November 19, 2001, vol. 375, col. 35.

${ }^{7}$ Hansard (HC), June 21, 2005, vol. 435, col. 668.

${ }^{8}$ No. T20147226, Leicester Crown Court, February 6, 2015 (unreported).

${ }^{9}$ Transcript obtained from Margaret Wort \& Co.

${ }^{10}$ Consider, for example, the Anti-terrorism, Crime and Security Act 2001, the Prevention of Terrorism Act 2005, and the Terrorism Act 2006.

${ }^{11}$ See footnote 2 above.

12 For example, when in 1994 two Lords suggested amendments to the Criminal Justice and Public Order Bill to include new stirring up religious hatred offences, the then Labour Party Shadow Home Secretary, Tony Blair, neither came out in support 
of these Lords Amendments nor tabled his own similar amendment in the House of Commons. During one commons debate on the Criminal Justice and Public Order Bill in January 1994 Blair rose to interrupt the then Home Secretary, Michael Howard, on so many occasions that the latter ultimately resorted to instructing Blair to 'Sit down'. Hansard (HC) January 11, 1994, vol. 235, col. 30. In that debate Blair tabled an amendment consisting of a list of ten additional measures including 'measures to strengthen the law on racial harassment and violence', but the list did not include a new stirring up religious hatred offences. Ibid., cols. 34-35. Moreover, as Prime Minister, Tony Blair made no mention of introducing this new offence in his 'Britain is stronger together' speech in 2000. Tony Blair, Speech to the Association of Regional Newspaper Executives, March 28, 2000. Nor in his 'Values and the power of community' speech in 2000. Tony Blair, Speech to the Global Ethics Foundation, Tübigen University, Germany, June 30, 2000.

13 Evidence from the UK policy agendas dataset, available at: www.policyagendas.org.uk. The Queen's Speech (or Speech from the Throne) sets out the executive and legislative priorities of the government in the forthcoming session. This supplies a powerful signal of the intentions of the executive to the public and acts as a means of setting out the political agenda for the forthcoming year.

${ }^{14}$ No mention of introducing such an offence appeared in either the 1997 or the 2001 Labour Party general election manifestos.

${ }^{15}$ Hansard (HL), November 27, 2001, vol. 629, col. 189.

16 A blank version of Clarke's letter appears on the following website: http://www.civitas.org.uk/pdf/ClarkeLetter.pdf.

${ }^{17}$ Hansard (HC), June 21, 2005, vol. 435, col. 737.

${ }^{18}$ No. T20027343, Central Criminal Court, March 7, 2003 (unreported).

${ }^{19}$ Transcript obtained from Smith Bernal Reporting Ltd.

${ }^{20}$ No. T20010599, Southwark Crown Court, May 3, 2002 (unreported).

${ }^{21}$ No. (unknown), Central Criminal Court, February 7, 2006 (unreported).

${ }^{22}$ No. T20150244, Central Criminal Court, July 5, 2007 (unreported).

${ }^{23}$ T20067103, Central Criminal Court, January 5, 2007 (unreported).

${ }^{24}$ No. T20077199, Central Criminal Court, February 1, 2007 (unreported).

${ }^{25}$ No. T20107575, Bristol Crown Court, July 29, 2011 (unreported). 
${ }^{26}$ Transcript obtained from Mendip-Wordwave Partnership.

${ }^{27}$ Charles Clarke, Secretary of State for the Home Office, Press Release: Tackling Terrorism-Behaviours Unacceptable in the UK, August 24, 2005.

${ }^{28}$ See, e.g., Prime Minister's Press Conference, August 5, 2005.

${ }^{29}$ [2010] EWHC 2825 (Admin.).

${ }^{30}$ Ibid., para. 71. See also para. 83.

${ }^{31} R$ (Naik) v Secretary of State for the Home Department [2011] EWCA (Civ.) 1546.

${ }^{32}$ Gordon Brown, National Security Statement, November 14, 2007.

33 The Secretary of State for the Home Department, Prevent Strategy (London: The Stationary Office, 2011), p. 1.

${ }^{34}$ Ibid., p. 27.

${ }^{35}$ Hansard (HC), November 19, 2001, vol. 375, cols. 34-35.

${ }^{36}$ Ibid.

${ }^{37}$ Consider the conviction of the Black Liberation Movement leader Michael Abdul Malik in R. v. Malik [1968] 1 All ER 582 (CA).

${ }^{38}$ Hansard (HL), October 11, 2005, vol. 674, col. 229.

${ }^{39}$ Hansard (HL) November 27, 2001, vol. 629, col. 194.

${ }^{40}$ Ibid., col. 211.

${ }^{41}$ Hansard (HC) February 15, 2006, vol. 442, col. 1429.

42 Theresa May, Speech to The Royal United Services Institute (RUSI), London, November 24, London.

${ }^{43}$ Cf. Gary P. Freeman, 'Modes of Immigration Politics in Liberal Democratic States' International Migration Review 29 (1995): 881-902.

${ }^{44}$ House of Lords Select Committee on Religious Offences in England and Wales, Report, April 10, 2003, para. 95.

${ }^{45}$ Hansard (HC), November 19, 2001, vol. 375, col. 34.

${ }^{46}$ David Blunkett, Speech to the Institute of Public Policy Research, July 7, 2014.

47 Commission on British Muslims and Islamophobia, Islamophobia issues, challenges and action (Stoke on Trent: Trentham Books, 2004).

${ }^{48}$ Crown Prosecution Service, Anti-Muslim Hate Crime: Learning From Casework (London: Equality and Diversity Unity, 2012), p. 17. 
${ }^{49}$ Home Office, Office for National Statistics and Ministry of Justice, An Overview of Hate Crime in England and Wales (Titchfield: Office for National Statistics, 2013), p. 23.

${ }^{50}$ Ibid., p. 20.

51 s. 4 A of the Public Order Act 1986, along hate crime provisions in the Crime and Disorder Act 1998 (as amended by s. 39 of the Anti-Terrorism, Crime and Security Act 2001) or in the Criminal Justice Act 2003.

${ }^{52}$ Matthew Feldman and Mark Littler, Tell MAMA Reporting 2013/14: Anti-Muslim Overview, Analysis and 'Cumulative Extremism' (Middlesbrough: Teeside University, 2014), Para. 2.4.

${ }^{53}$ See, e.g., The Geography of Anti-Muslim Hatred: Tell MAMA Annual Report 2015 (London: Faith Matters, 2016), pp. 21-23.

${ }^{54}$ Feldman and Littler, Tell MAMA Reporting 2013/14, para. 2.4.

${ }^{55}$ No. 94/2421/X2, Court of Appeal, April 11, 1995, 6 Archbold News 2.

${ }^{56}$ No. (unknown), Central Criminal Court, November 4, 2005 (unreported).

${ }^{57}$ No. T20080094, Leeds Crown Court, July 10, 2009 (unreported).

${ }^{58}$ No. T20107203, Liverpool Crown Court, June 25, 2010 (unreported).

${ }^{59}$ No. (unknown), Southwark Crown Court, December 2015 (unreported).

${ }^{60}$ Compare Parts 3 and 3A of the Public Order Act 1986.

${ }^{61}$ s. 29J of the Public Order Act 1986.

${ }^{62}$ In line with the Salisbury Convention the House of Lords is expected to avoid opposing out of hand legislation promised in the government's election manifesto. For the first time, the 2005 Labour Party Manifesto included 'a firm and clear intention to give people of all faiths the same protection against incitement to hatred on the basis of their religion.' www.politicsresources.net/area/uk/man.htm. Nevertheless, the House of Lords exercised its prerogative - arguably its central function - to dissect proposed legislation and put forward amendments designed to improve that legislation based on the insights of relevantly experienced peers. Whilst under the Parliament Acts the House of Lords cannot block indefinitely government legislation, it can slow it down sufficiently to make it extremely difficult for a government to have its own way on the finer details of legislation, because of the scarcity of parliamentary time. In that sense it is not simply a case of the government of the day introducing new 
legislation but both Houses of Parliament working in conjunction under a multilayered system of majority voting, with a government, even one that has a healthy majority in the House of Commons, sometimes winning, sometimes losing.

${ }^{63}$ See Law Commission, Hate Crime: The Case for Extending the Existing Offences, Appendix B, p. 45.

64 Hansard (HC) Criminal Justice and Immigration Bill, Public Bill Debate (Afternoon), October 16, 2007, cols. 74-85.

${ }^{65} \mathrm{https} / / /$ petition.parliament.uk/petitions/163896.

${ }^{66}$ See, e.g., Gary P. Freeman, 'National Models, Policy Types, and the Politics of Immigration in Liberal Democracies', West European Politics 29 (2006): 227-247.

${ }^{67}$ Bhikhu Parekh, The Future of Multi-Ethnic Britain: Report of the Commission on the Future of Multi-Ethnic Britain (London: Profile Books, 2000), p. 90.

${ }^{68}$ Ibid., p. 61.

${ }^{69}$ Commission for Racial Equality, Second Review of the Race Relations Act 1976 (London: Commission for Racial Equality, 1992).

70 [1983] UKHL 7.

${ }^{71}$ Commission for Racial Equality, Second Review of the Race Relations Act 1976.

${ }^{72}$ Hansard (HC), June 21, 2005, vol. 435, col. 678.

${ }^{73}$ Hansard (HL), October 11, 2005, vol. 674, col. 229.

${ }^{74}$ Ibid., col. 209.

${ }^{75}$ Ibid., col. 219.

${ }^{76}$ See Law Commission, Hate Crime: The Case for Extending the Existing Offences, Appendix B, p. 10.

77 s. 5 of the Public Order Act 1986, along with the Crime and Disorder Act 1998 (as amended by s. 39 of the Anti-Terrorism, Crime and Security Act 2001).

78 [2003] EWHC 1564 (Admin.).

${ }^{79}$ Hansard (HC) October 8, 2007, vol. 464, col 59.

${ }^{80}$ Equality and Human Rights Commission, Hidden in Plain Sight (London: Equality and Human Rights Commission, 2011) at p. 154.

81 The Law Commission, Hate Crime: Should The Current Offences Be Extended? (Paper No 348) (London: The Stationery Office, 2014), paras 7.12 and 7.17. 
82 House of Commons Women and Equalities Committee, Transgender Equality, First Report of Session 2015-16, January 14, 2016, at paras. 269-72.

${ }^{83}$ Ibid., para 275.

${ }^{84}$ (1988) IRLIB 367.

${ }^{85}$ See Ivan Hare, 'Crosses, Crescents and Sacred Cows: Criminalising Incitement to Religious Hatred', Public Law (2006): 521-537, p. 533; Alexander Brown, 'The "Who?" Question in the Hate Speech Debate: Part 1: Consistency, Practical, and Formal Approaches', Canadian Journal of Law and Jurisprudence 29 (2016): 275320, pp. 283-4, pp. 287-92.

${ }^{86}$ Home Office, Action Against Hate: The UK Government's Plan for Tackling Hate Crime (London: Home Office, 2016), para. 111.

${ }^{87}$ Law Commission, Hate Crime: Should The Current Offences Be Extended?.

${ }^{88}$ See Hare, 'Crosses, Crescents and Sacred Cows: Criminalising Incitement to Religious Hatred', p. 533.

${ }^{89}$ Brown, 'The "Who?" Question in the Hate Speech Debate: Part 1', pp. 284, 288-90.

90 See, e.g., Bhikhu Parekh, Rethinking Multiculturalism: Cultural Diversity and Political Theory, Second Edition (Basingstoke: Palgrave, 2006), ch. 10; Alexander Brown, Hate Speech Law: A Philosophical Examination (London: Routledge, 2015), ch. 6 .

${ }^{91}$ See Brown, 'The "Who?” Question in the Hate Speech Debate: Part 1', pp. 283-93. 92 Alon Harel, 'Bigotry, Pornography, and the First Amendment: A Theory of Unprotected Speech', Southern California Law Review 65 (1992): 1887-1931, p. 1906.

93 Jeremy Waldron, 'Dignity and Defamation: The Visibility of Hate', Harvard Law Review 123 (2010): 1596-1657.

${ }^{94}$ See Brown, Hate Speech Law, pp. 152-6; Alexander Brown, 'The "Who?" Question in the Hate Speech Debate: Part 2: Functional and Democratic Approaches', Canadian Journal of Law and Jurisprudence 30 (2017): 23-55, pp. 29-30.

${ }^{95}$ See Brown, Hate Speech Law, pp. 26-27.

${ }^{96}$ See, e.g., C. Edwin Baker, 'Hate Speech', in M. Herz and P. Molnar (eds.) The Content and Context of Hate Speech: Rethinking Regulation and Responses (Cambridge: Cambridge University Press, 2012); Ronald Dworkin, 'Reply to Jeremy 
Waldron', in M. Herz and P. Molnar (eds.) The Content and Context of Hate Speech: Rethinking Regulation and Responses (Cambridge: Cambridge University Press, 2012); Robert Post, 'Interview', in M. Herz and P. Molnar (eds.) The Content and Context of Hate Speech: Rethinking Regulation and Responses (Cambridge: Cambridge University Press, 2012); Nadine Strossen, 'Interview', in M. Herz and P. Molnar (eds.) The Content and Context of Hate Speech: Rethinking Regulation and Responses (Cambridge: Cambridge University Press, 2012); Eric Heinze, Hate Speech and Democratic Citizenship (Oxford: Oxford University Press, 2016); James Weinstein, 'Hate Speech Bans, Democracy and Political Legitimacy', Constitutional Commentary, forthcoming.

${ }^{97}$ See, e.g., Susannah C. Vance, 'The Permissibility of Incitement to Religious Hatred Offences Under European Convention Principles', Transnational Law and Contemporary Problems 14 (2004): 201-251; Hare, 'Crosses, Crescents and Sacred Cows: Criminalising Incitement to Religious Hatred'; Ivan Hare, 'Blasphemy and Incitement to Religious Hatred: Free Speech Dogma and Doctrine' in I. Hare and J. Weinstein (eds.) Extreme Speech and Democracy (Oxford: Oxford University Press, 2009); Peter Cumper, 'Outlawing Incitement to Religious Hatred: A British Perspective', Religion and Human Rights 1 (2006): 249-268; David Nash and Chara Bakalis, 'Incitement to Religious Hatred and the 'Symbolic': How will the Racial and Religious Hatred Act 2006 work?', Liverpool Law Review 28 (2007): 349-375; Kay Goodall, 'Incitement to Religious Hatred: All Talk and No substance?' Modern law review 70 (2007): 89-113; Eric Barendt, 'Religious Hatred Laws: Protecting Groups or Belief?' Res Publica 17 (2011): 41-53.

${ }^{98}$ See, e.g., Alexander Brown, 'The Racial and Religious Hatred Act 2006: A Millian Response', Critical Review of International Social and Political Philosophy 11 (2008): 1-24; Simon Thompson, 'Freedom of Expression and Hatred of Religion', Ethnicities 12 (2012): 215-232.

99 See, e.g., Brown, 'The Racial and Religious Hatred Act 2006', pp. 13-14; Brown, Hate Speech Law, pp. 66-75; Brown, 'The "Who?" Question in the Hate Speech Debate: Part 2', pp. 27-29. Of course, some people argue that even though security is the sort of value that has the normative stature to hold its own against arguments for freedom of expression based on autonomy and democracy, the threat to security from 
the stirring up of hatred is not sufficiently imminent to justify the cost to freedom of expression. See, e.g., Peter Molnar, 'Responding to "Hate Speech" with Art, Education, and the Imminent Danger Test', in M. Herz and P. Molnar (eds.) The Content and Context of Hate Speech: Rethinking Regulation and Responses (Cambridge: Cambridge University Press, 2012). Other people claim that allowing such arguments inevitably creates a slippery slope to hate speech laws that cover every protected characteristic going, which is devastating for free speech. See, e.g., Eric Heinze, 'Cumulative Jurisprudence and Hate Speech: Sexual Orientation and Analogies to Disability, Age, and Obesity', in I. Hare and J. James Weinstein (eds.) Extreme Speech and Democracy (Oxford: Oxford University Press, 2009). And some people also maintain that the preponderance of evidence would suggest that laws banning the stirring up of hatred are ineffective at best at reducing this sort of speech and the security threats associated with it. See, e.g., Eric Heinze, Hate Speech and Democratic Citizenship (Oxford: Oxford University Press, 2016). For counters to all of these arguments, see Brown, Hate Speech Law, pp. 66-75, 239-242; Brown, 'The “Who?” Question in the Hate Speech Debate: Part 2', esp. p. 54.

${ }^{100}$ No. T20110109, Derby Crown Court, February 10, 2012 (unreported).

101 Transcript obtained directly from Judge Burgess.

${ }^{102}$ Brown, 'The "Who?” Question in the Hate Speech Debate: Part 2', pp. 30-31. 